\title{
The Limits of Social Democracy
}


A volume in the series

Cornell Studies in Political Economy Edited by Peter J. Katzenstein

A full list of titles in the series appears at the end of the book. 


\title{
The Limits of \\ Social Democracy
}

\author{
INVESTMENT \\ Politics in Sweden
}

Jonas Pontusson

Cornell University Press

Ithaca and London 


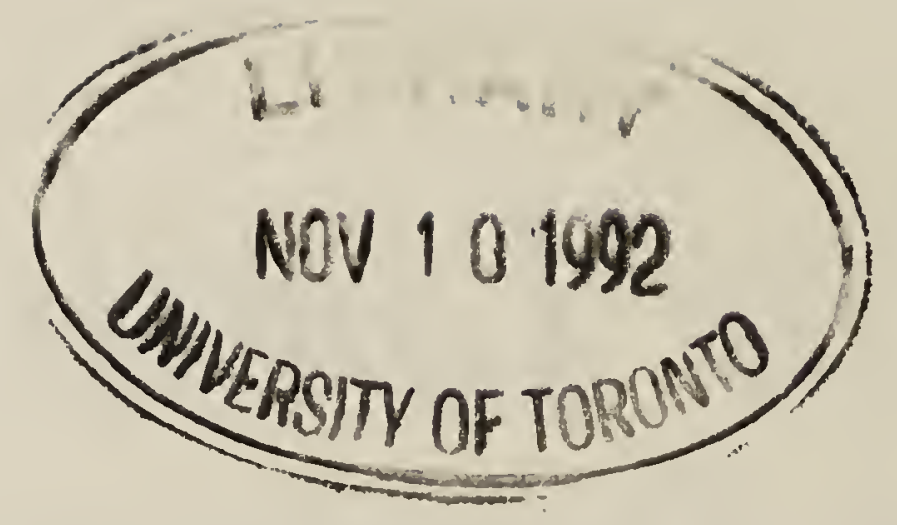

THIS BOOK HAS BEEN PUBLISHED WITH THE AID OF A GRANT

FROM THE HULL MEMORIAL PUBLICATION FUND OF CORNELL UNIVERSITY.

\section{Copyright (C) 1992 by Cornell University}

All rights reserved. Except for brief quotations in a review, this book, or parts thereof, must not be reproduced in any form without permission in writing from the publisher. For information, address Cornell University Press, 124 Roberts Place, Ithaca, New York $1485^{\circ}$.

First published $199^{2}$ by Cornell University Press.

International Standard Book Number o-8014-2652-9

Library of Congress Catalog Card Number 92-2694

Printed in the United States of America

Librarians: Library of Congress cataloging information appears on the last page of the book.

(2) The paper in this book meets the minimum requirements of the American National Standard for Information SciencesPermanence of Paper for Printed Library Materials, ANSI Z39.48-1984. 